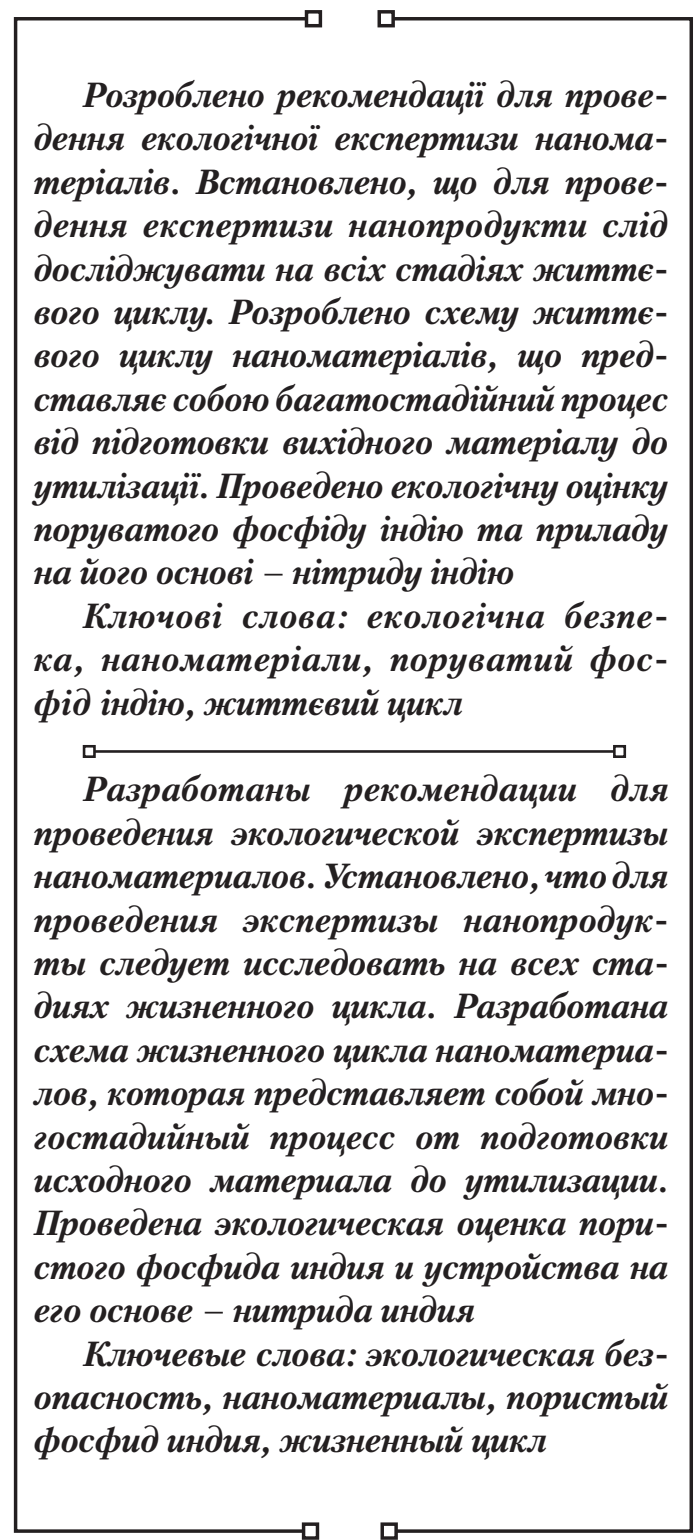

Over the past decades, nanotechnologies have become strategic industrial direction. In many areas of science and technology and sectors of industry, there is a great interest in the products of nanotechnology, which is associated with the real possibility of practical implementation of their unique properties. More than 50 countries conduct research and development in the field of nanotechnology and not less than 30 countries have their own national programs in this area [1]. According to official data of the StatNano website, in 2016, the Office for patents and trademarks of the United States granted 8484 patents in the field of nanoindustry [2]. Nanomaterials are widely used as basic material for photovoltaic converters [3, 4], lasers and LEDs [5, 6], buffer layers for making heterostructures [7], etc.

Nanotechnologies traditionally include designs, in which materials and systems are used that meet three criteria:

UDC 504:620.3

DOI: $10.15587 / 1729-4061.2017 .85847$

\section{ANALYSIS OF THE WAYS TO PROVIDE ECOLOGICAL FETY FOR THE PRODUCTS OF NANOTECHNOLOGIES THROUGHOUT THEIR LIFE CYCLE}

S. V a m bol

Doctor of Technical Sciences, Professor, Head of Department Department of Applied Mechanics*

E-mail: sergvambol@nuczu.edu.ua

V. Va m bol

Doctor of Technical Sciences, Professor

Department of Labour Protection and

Technogenic and Ecological Safety*

E-mail: violavambol@nuczu.edu.ua

Y. S u chi k ova

$\mathrm{PhD}$, Associate Professor

Department of Vocational Education

Berdyansk State Pedagogical University

Schmidta str., 4, Berdyansk, Ukraine, 71100

E-mail: yanasuchikova@mail.ru

N. De y n e k o

$\mathrm{PhD}$

Scientific Aepartment of Civil Protection Issues and Man-Caused Environmental Safety Research Center*

E-mail: natalyadeyneko@nuczu.edu.ua

*National University Of Civil Protection of Ukraine

Chernishevska str., 94, Kharkiv, Ukraine, 61023

- at least one of their spatial dimensions does not exceed $100 \mathrm{~nm}$;

- processes based on fundamental control over the physical and chemical properties of molecular structures are used for their manufacturing;

- they can be incorporated into larger structures.

The penetration of nanoparticles into the biosphere can lead to many consequences, which are currently impossible to predict due to the lack of information. Researchers note that toxicity of nanomaterials is largely associated with impurities existing in them, rather than with materials themselves [8]. However, information about the consequences of the uncontrolled emission of nanoparticles in the environment remains quite scarce.

American Society for Testing and Materials (ASTM) developed the standards. They relate to the terms in the field of nanotechnologies, methods of measurement and characteristics of nanoparticles as well as specification of nanomaterials [9]. Within the framework of ISO/TC 229, country-curators of individual areas of metrology, standard- 
ization and certification were defined. Metrology, measurement and testing techniques are assigned to Japan, terms and definitions - to Canada, problems of health, safety and environment - to the USA. In the field of nanotechnology in Japan, the share of funding of works that study the risk of negative impact on health and environment reaches $30 \%$ [10].

All mentioned above indicates relevance and the need to search for the ways to provide ecological safety of nanotechnology products throughout their life cycle for their further improvement.

\section{Literature review and problem statement}

Widespread implementation of nanotechnologies in industry is predetermined by a number of factors that include: - depletion of natural resources and the possibility of replacing rare materials with metamaterials [11, 12];

- miniaturization of electronics products [13, 14];

- advent of new industries [15, 16].

Nanoindustry develops rapidly and, due to this, attraction of investment from government and businesses to this sector is growing around the world. At the same time, more and more researchers acknowledge that the use of nanomaterials may pose a danger to human health and environment [17, 18].

Authors of paper [19] stress the need to take into account the lifecycle approach to nanoproducts when evaluating their possible impact on the environment and human health. Method of assessment of nanomaterials, which includes a risk assessment "Nano LCRA" and comprehensive ecological assessment, was proposed. However, the authors indicate that this technique has a general character, and requires further detailed specification.

Studies have shown that the quality of nanomaterials, which make them popular, may pose a potential ecological threat. Today it is important to make a decision: either to use potentially dangerous materials or to refuse from them in favour of ecologically friendly and those that are sufficiently studied.

With this in mind, paper [20] proposes to conduct analysis of nanotechnologies with regard to four principles:

- before applying nanotechnology products, to make a comparative analysis of all alternative solutions to the set task after obtaining complete information about a possible threat to biological components of environment;

- to determine quantitavely the nature of compromises associated with existing choice of alternatives;

- nanomaterials and structural elements on their basis should be considered as a united system;

- analysis of risk and sense of using nanotechnology products should be comprehensible for consumers.

However, the authors do not provide a clear mechanism for the quantitative detection of risks and methods of general analysis of the products of nanotechnology. It should also be taken into account that is not always possible to receive full information about possible danger of nanomaterial.

In paper [21], authors demonstrate that standard toxicological methods cannot be applied to determine the hazards of nanomaterials. This is explained by the fact that the properties of the latter are caused not by concentration in the volume of material, but rather by its quantodimensional properties.

Thus, one can argue that many scientists point to potential dangers of nanotechnology products for the environment and human health. However, in this case, there is no systematic approach to determining the extent of danger of nanomaterials throughout their life cycle. Methods for detecting this danger at different stages of synthesis and the use of nanoindustry products have not been determined up to now, nor have been explored the problems of ecological safety of nanotechnology application.

\section{The aim and tasks of the study}

Conducted studies were aimed at searching for the ways of providing ecological safety for nanotechnology products throughout their life cycle.

To accomplish the set aim, the following tasks were to be solved:

- to establish main stages of the life cycle of nanomaterials that require research and control of their safety;

- to identify the main purpose of ecological evaluation of nanotechnological products;

- to develop recommendations as for the provision of ecological safety for nanotechnology products throughout their life cycle.

\section{Materials and methods of studying basic indicators of control over nanotechnology products}

\subsection{Development of the scheme of nanomaterials life} cycle

A comprehensive research into the risks of using nanomaterials and controlling their impact on the environment and the human body is a long-lasting and scientifically complicated process. In addition, there are no sufficient data on the toxicity of large quantities of nanomaterials and labeling and passports have not been developed for most of them. That is why we will focus only on general types of nanoindustry influence on the ecosystem and humans.

To do this, one must clearly understand that nanomaterials may pose a danger not only in the course of their usage, but at all stages of their life cycle, the simplified schematic of which is shown in Fig. 1.

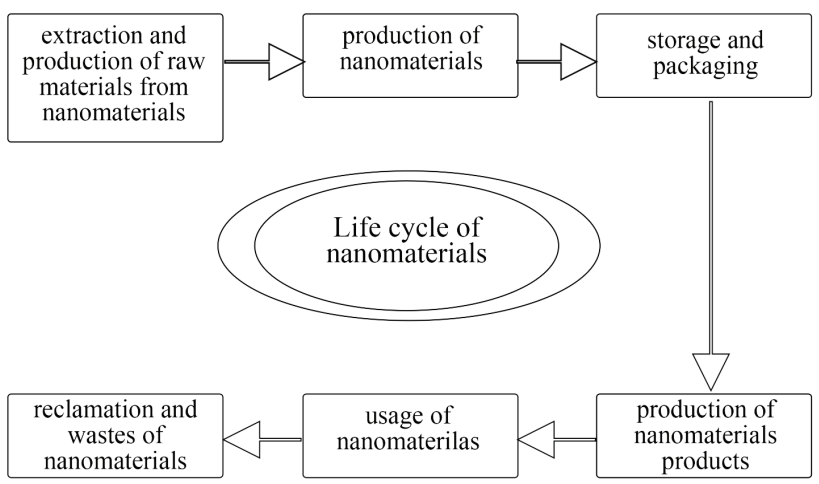

Fig. 1. Schematic of life cycle of nanomaterials

Thus, in the process of ecological assessment of nanomaterials, specific features of each stage of the life cycle should be taken into account. Hence, at the first stage of "Extraction and production of raw materials from nanomaterials", one should consider substances of which the nanoproduct is made. 
The second stage of "Production of nanomaterials" is directly related to the methods of synthesis of nanomaterials, which may conditionally be divided into physical, chemical, and chemical-physical. At this stage, the pargest threat is caused by the substances involved in nanomaterial production (electrolytes, ions, powders, gases, etc.) and the methods of synthesis.

At the third stage of "Storage and packaging", it is necessary to take into consideration specific features of materials, their volatility, solubility, interaction with air and water, etc.

As a rule, nanomaterials are made with the view to their further integration into products or industrial produce. Thus, the fourth stage of "Production of nanomaterials products" is an essential element in examining the life cycle of nanoproduce. At this stage, testing and identifying the quality and suitability of nano-raw materials for later use is carried out. That is why a significant percentage of nanomaterials is rejected and requires liquidation or recycling.

"Usage of nanomaterials", which is the fifth stage of the life cycle of a nanoproduct, regards products containing nano raw materials. Therefore, research should be comprehensive, taking into account not only physical and chemical characteristics of substances, but also behavior of the whole product and its components during the operation period.

When analyzing the last stage of the life cycle "Reclamation and wastes", it should be taken into consideration that nanomaterial exists as a component of the product, which is why its separation is impossible in many cases. Then the reclamation of the entire product is necessary.

\subsection{Procedure of making up guidelines to control} nanomaterials

In general, sanitary-epidemiological examination is carried out in order to detect:

- products, which pose a danger for human life and health;

- products, manufacturing, circulation and consumption (using) of which may have a possibility of causing harm to human health.

When using nanoindustry products, it is necessary to assess compliance/noncompliance of products, terms of its manufacturing and usage with current legislation and international standards.

Most studies of assessing the risks related to nanomaterials refer to particular, homogeneous nanomaterials that are characterized by a high degree of purity. However, heterostructures, that contain nanofilms of different composition, are very often used. In addition, it is necessary to focus attention on such indicators as:

- total amount of resources, used for creation of nanoproduce;

- ageing of nanomaterials; methods of treatment and incorporation of nanomaterials in a commercial product;

- basic characteristics of the original material that was used to create nanostructures, etc.;

- change in properties of nanomaterials throughout life cycle.

Considering the aforementiones, there is a need for creating a system of nanosafety and certification of nanoindustry produce. General schematic of this approach should include a number of measures (Fig. 2).

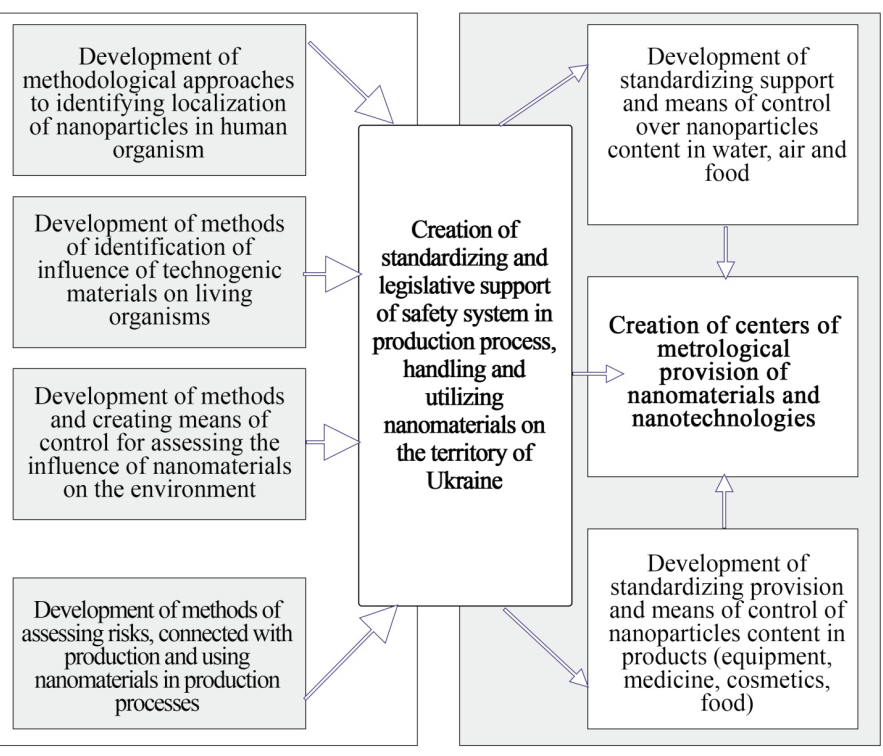

Fig. 2. General diagram of creating standardizing, legislative and methodological support of ecological safety in the process of operation of nanomaterials

A manufacturer must provide full information on the nanomaterial according to the procedure shown in Fig. 3.

\begin{tabular}{|c|c|c|}
\hline 1 & Product name & $\begin{array}{l}\text { product name must correspond exactly to the one } \\
\text { indicated on the label; form }\end{array}$ \\
\hline 2 & Usage area & $\begin{array}{l}\text { technological purpose (raw material, intermediate } \\
\text { product, purpose-oriented product, etc.) }\end{array}$ \\
\hline 3 & $\begin{array}{l}\text { Information about } \\
\text { manufacturer }\end{array}$ & $\begin{array}{l}\text { full official name, address, telephone, fax, e-mail } \\
\text { address, site (if available) }\end{array}$ \\
\hline 4 & $\begin{array}{l}\text { Nanoparticles content } \\
\text { in material }\end{array}$ & $\begin{array}{l}\text { mass or/and number of particles on conversion to } \\
\text { mass/ volume unit of product }\end{array}$ \\
\hline 5 & Chemical composition & $\begin{array}{l}\text { by systematic or trivial nomenclature, formula, } \\
\text { molecular weight }\end{array}$ \\
\hline 6 & $\begin{array}{l}\text { Average dimensions } \\
\text { of particles }\end{array}$ & $\begin{array}{l}\text { specific surface on conversion to distribution of } \\
\text { particles by dimensions }\end{array}$ \\
\hline 7 & $\begin{array}{l}\text { Content of } \\
\text { cancerogens }\end{array}$ & according to hygienic norms \\
\hline 8 & Impurities & composition, concentration \\
\hline 9 & Solubility & in water, lipid and different media \\
\hline 10 & Methods of research & $\begin{array}{l}\text { provide the proof of existence of nanoparticles in } \\
\text { the product or classification as nanomaterial }\end{array}$ \\
\hline 11 & $\begin{array}{l}\text { Method of obtaining } \\
\text { nanomaterials }\end{array}$ & $\begin{array}{l}\text { by dispersion, by condensation from gas phase, } \\
\text { solubility methods, other }\end{array}$ \\
\hline 12 & $\begin{array}{l}\text { Hazard class } \\
\text { of product }\end{array}$ & according to GOST (State Standard) 12.1.007-76 \\
\hline 13 & $\begin{array}{l}\text { Possible technogenic } \\
\text { risks }\end{array}$ & if any \\
\hline 14 & $\begin{array}{l}\text { Toxicological } \\
\text { and hygienic }\end{array}$ & $\begin{array}{l}\text { general toxical and irritation action, allergenity, } \\
\text { cancerogenity, mutagenity }\end{array}$ \\
\hline 15 & $\begin{array}{l}\text { Impact on } \\
\text { environment }\end{array}$ & $\begin{array}{l}\text { migration to ecological objects, stability, } \\
\text { biodegradability }\end{array}$ \\
\hline 16 & $\begin{array}{l}\text { Rules of handling } \\
\text { and storage }\end{array}$ & $\begin{array}{l}\text { which exclude possibility of non-sanctioned } \\
\text { influence of product and its components }\end{array}$ \\
\hline 17 & Reclamation & $\begin{array}{l}\text { procedure of safe neutralization, utilization and } \\
\text { disposal of nanoindustry products }\end{array}$ \\
\hline 18 & $\begin{array}{l}\text { Standardizing and } \\
\text { legislative provision }\end{array}$ & $\begin{array}{l}\text { information on legislation in field of rules of safe } \\
\text { production, circulation and utilization }\end{array}$ \\
\hline
\end{tabular}

\section{Fig. 3. Recommended procedure to control nanomaterials}

It should be noted that specific properties of nanomaterials may vary for each individual case, even with the same chemical formula and method of obtaining. This fact complicates classification and labelling of nanomaterials. In 
addition, most indicators are defined not for all substances, and this definition is often impossible because of the lack of necessary equipment or even a method of definition.

\section{Results of conducting control of nanomaterials on the example of porous indium phosphide}

As an experimental nanomaterial, we selected porous indium phosphide (por-InP), which was obtained on the substrate of monocrystalline indium phosphide by the method of electrochemical etching in the solution of hydrochloric acid.

\section{1. Analysis of stages in the life cycle of porous indi-} um phosphide and the product based on it

Given the general scheme of nanomaterial life cycle, it is expedient to compose LCA of por-InP and of the product based on it. This should take into account the intermediate stages - testing and sorting the samples (Fig. 4). We will accept indium nitride ( $\mathrm{InN} /$ por-InP), which is widely used in optoelectronics, photoelectric and photovoltaic devices as a product based on porous indium phosphide [22].

An important point is to understand the fact that porous indium phosphide is a specific form of monocrystalline indium phosphide, so the general properties of both materials will be the same, while specific properties may vary.

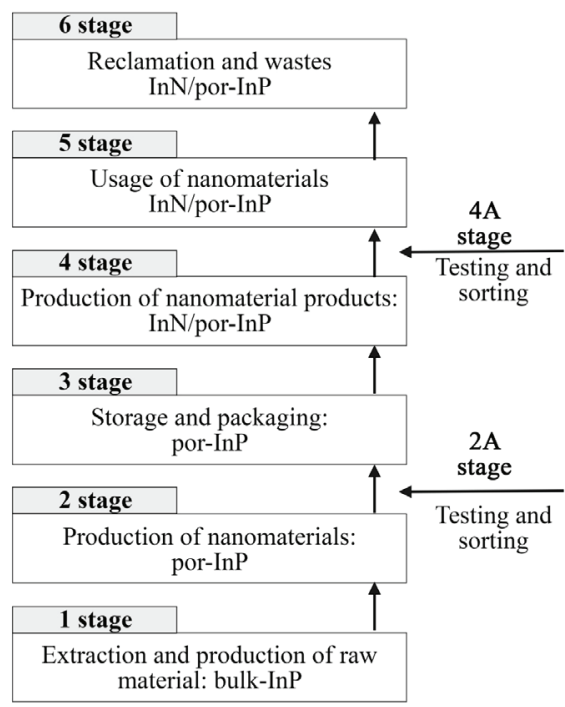

Fig. 4. Life cycle of porous indium phosphide and indium nitride based on it

Stage 1 "Extraction and production of raw material bulk-InP”

Porous indium phosphide is made at the surface of monocrystalline indium phosphide (mono-InP or bulkInP). In its turn, monocrystalline indium phosphide is made by the Cokhralsky method (Fig. 5) with liquid hermetic sealing of melt (LEC) and by the method of vertical directional crystallization (VGF). The peculiarity of the technology of InP cultivation lies in the fact that both methods are implemented at high pressure of inert gas or phosphorus in the chamber. The obtained ingots of indium phosphide are cut into plates and polished (Fig. 5, b). General and physical and chemical properties of indium phosphide are shown in Table 1.
Table 1

Properties of indium phosphide

\begin{tabular}{|c|c|}
\hline Type of crystal lattice & Sphalerite (Fig. 5, c) \\
\hline Constant of lattice & $5,8687 \mathrm{~A}$ at $300 \mathrm{~K}$ \\
\hline Relative molecular weight & 144,63 \\
\hline Number of atoms in $\mathrm{cm}^{3}$ & $3,96 \times 10^{22}$ \\
\hline Density in solid state & $4,81 \mathrm{~g} / \mathrm{cm}^{3}$ \\
\hline $\begin{array}{c}\text { Melting temperature under } \\
\text { pressure of phosphorus vapors }\end{array}$ & $1060^{\circ} \mathrm{C}$ \\
\hline $\begin{array}{c}\text { Dielectric permittivity of } \\
\text { indium phosphide }\end{array}$ & $\begin{array}{c}\text { Static }-12,5 ; \\
\text { high frequency }-9,61\end{array}$ \\
\hline Width of forbidden zone & $1,35 \mathrm{eV}$ \\
\hline Volatile impurities & $\begin{array}{c}\text { for n-type }-\mathrm{S}, \mathrm{Se}, \\
\text { Te, Si, Ge, Sn; } \\
\text { for p-type }-\mathrm{Zn}, \mathrm{Cd}\end{array}$ \\
\hline nolubility in water & noluble \\
\hline Solvents & $\begin{array}{c}\text { hydrochloric acid, } \\
\text { acid mixes }\end{array}$ \\
\hline
\end{tabular}

There are some data on cancerogenity of indium phosphide: according to the website of U.S. National Library of Medicine, indium phosphide is classified as a substance, probably cancerogenic to humans (Group 2A) [23]. The studies were carried out on mice and rats. Very important is the fact that an increase in cases of neoplasms occurred in rats and mice, subjected to exposure of extremely low concentrations of indium phosphide $\left(0.03-0.3 \mathrm{mg} / \mathrm{m}^{3}\right)$, and, more importantly, the number of cases increased in mice and rats that were exposed to this influence for only 22 weeks. In view of the foregoing, the plates of indium phosphide should be accompanied by a danger pictogram "Health hazard" (Fig. 5, $d$ ).

However, it should be taken into account that indium phosphide is usually presented in the form of crystalline plates that are thermodynamically and electrically stable in the air. So we can assume that the plates themselves do not pose a threat to life and health.
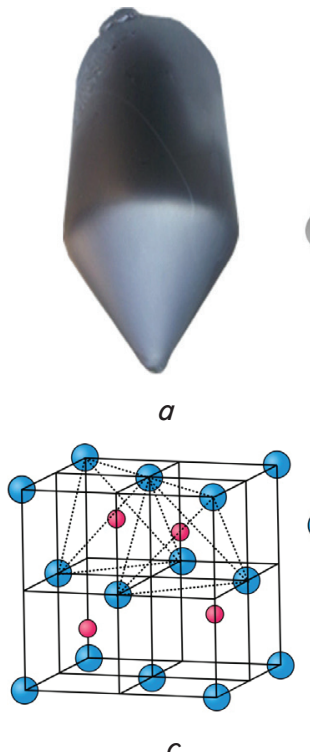

$c$

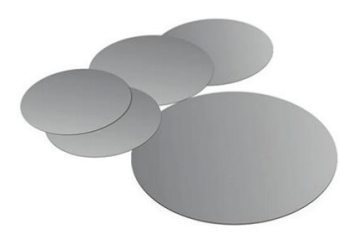

$b$

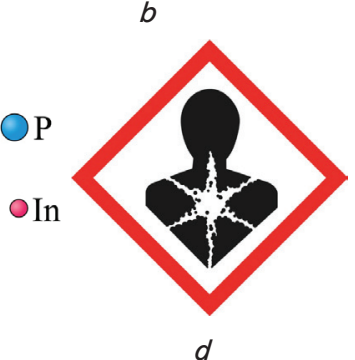

Fig. 5. Monocrystalline indium phosphide: $a$ - ingots of monocrystalline indium phosphide; $b$ - polished plates of indium phosphide; $c$ - crystal lattice of $\ln \mathrm{P}$;

$d$ - danger pictogram "Health hazard", which must accompany the plate of indium phosphide 
Stage 2 "Production of nanomaterials por-InP"

For the experiment, we selected 10 monocrystalline plates of n-type indium phosphide with surface orientation (111), alloyed with sulfur to the concentration of non-basic charge carriers $2.3 \times 10^{18} \mathrm{~cm}^{-3}$. Porous surface was formed in electrochemical cell with the $5 \%$ water solution of hydrochloric acid (Fig. 6). Fig. 7 shows the plate of indium phosphide after electrochemical treatment. Current density during the treatment was selected in the range of $70-150 \mathrm{~mA} / \mathrm{cm}^{2}$, at etching time of $5-15 \mathrm{~min}$. After etching, the samples were treated in the flow of liquid nitrogen.

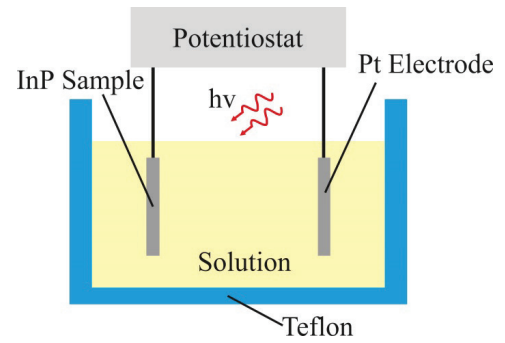

Fig. 6. Device for obtaining porous layers at the surface of monocrystals

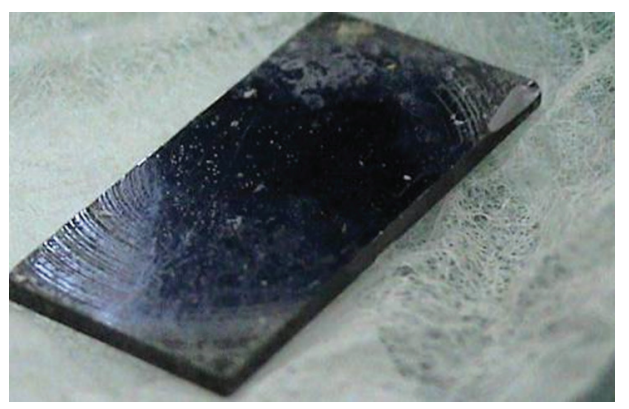

Fig. 7. Sample of indium phosphide with the porous layer, formed at it after electrochemical treatment in the solution of hydrochloric acid

In addition to hydrochloric acid, solutions of hydrofluoric, nitric, bromide acids, etc. often serve as solvents for indium phosphide. Given the fact that the solutions of acids are used for the formation of porous layers, it can be argued that this technology is not safe for human health. Moreover, during the experiment, the mode of electrolyte heating is often used to accelerate the process of penetration of ions into the holes of pores. That is why this experiment should be carried out with the use of means of collective and individual protection. The used electrolyte must be disposed of according to valid legislation requirements.

To study the properties of por-InP, we used the method of scanning electronic microscopy and EDAX method. As a result, a porous layer with tightly packed pores was formed at the surface (Fig. 8). Porous structure is a nanomaterial, consisting of deep cylindrical holes - pores and walls between them - quantum wires. These wires are nanostructures (Fig. 9).

Equivalent diameter of particles was determined by the method of using the mean projected diameter, which is the diameter of circle whose area is equal to the area of particle projection image (1), (2). Since the projection area of spherical particle is equal to:

$$
\mathrm{S}=\left(\pi \mathrm{d}^{2}\right) / 4
$$

then the mean projected diameter is calculated as:

$$
d=\sqrt{4 \frac{S}{T}}
$$

By the results of scanning electronic microscopy, it is possible to establish that dimensions of pores reach $40 \mathrm{~nm}$ on average. This indicates that this structure is mezoporous. Dimensions of walls between the pores are within $(5-10) \mathrm{nm}$ (Fig. 10).

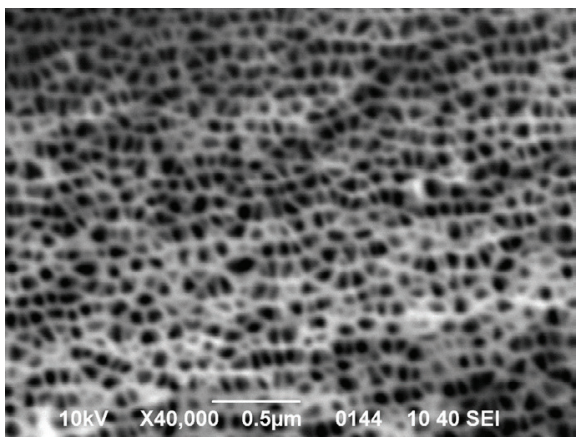

Fig. 8. SEM image of por-InP (100): $5 \% \mathrm{HCl}, \mathrm{j}=80 \mathrm{~mA} / \mathrm{cm}^{2}, \mathrm{t}=10 \mathrm{~m}$

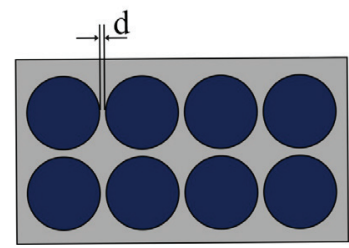

$a$

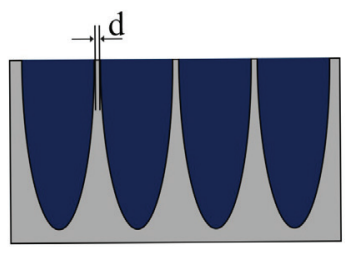

$b$
Fig. 9. Schematic representation of porous nanostructure: $a$ - surface with pores located at it; $b$ - split with inter-porous walls, which are the quantum wires with cross-sectional dimension d

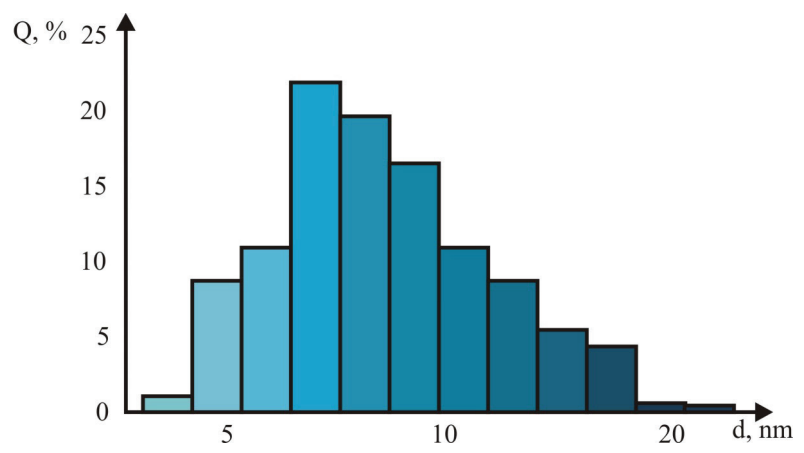

Fig. 10. Distribution of quantum wires by dimensions: $\mathrm{Q}$ is the share of particles, \%; $\mathrm{d}-$ dimensions of particles, $\mathrm{nm}$

Porosity degree of the sample is determined by the gravimetric method (weighing) at three stages: weighing monocrystalline plates; etching of porous layer on it and weighing; removal of the porous layer and repeated weighing. Next, porosity was determined by formula (3):

$$
\mathrm{H}=\left(1-\rho_{\text {por }} / \rho_{\text {InP }}\right) \times 100,
$$

where $\rho_{\text {por }}$ and $\rho_{\text {InP }}$ are the density of porous and monocrystalline materials. 
Thus, porosity of the obtained layers varies from 40 to $70 \%$. Fluctuation of surface porosity is caused by uneven concentration non-uniformity of distribution of impurity in the volume of ingot, which occurs during the crystal growth.

Chemical composition of porous samples was assessed using the EDAX method (Fig. 11). Based on results of these data, it may be concluded that the oxide film was not formed at the surface of porous por-InP, the existence of elements that make up the etcher was not observed either. However, crystal stoichiometry was broken in the process of etching: indium was present in larger concentrations than phosphorus.

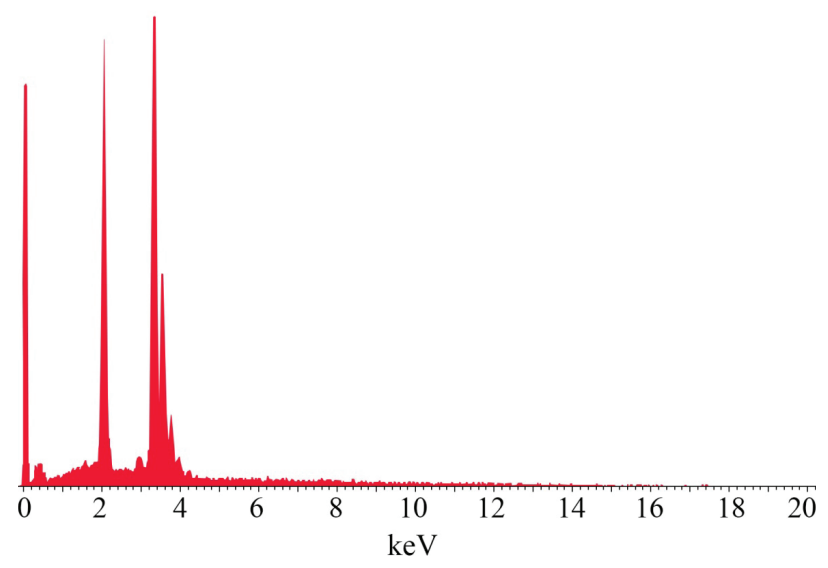

Fig. 11. Chemical composition of elements at the surface of por-InP

Obviously, porous layers of indium phosphide are very fragile. The top layer may shear off even in the contact with hands, forming a nanodispersed powder, which is a real threat to human health - such nanoparticles easily get into the respiratory tract and penetrate the skin. Indium excess creates an additional threat, as indium in its pure form is a toxic substance.

Stage 2 A "Testing and sorting"

Samples testing is conducted in order to identify the ones which are suitable for further use. Depending on the requirements for the quality of nanomaterials, different methods, such as visual inspection, electronic microscopy, photoluminiscence, X-ray diffractometry are used. In our case, the method of scanning electronic microscopy was applied. As a result, 2 layers out of 10 were rejected due to excessively severe conditions of etching (current density for them amounted to $150 \mathrm{~mA} / \mathrm{cm}^{2}$ ) - porous layer was separated from the monocrystalline substrate.

Stage 3 "Storage and packaging of por-InP"

A specific feature of por-InP is its ability of "ageing" in the open air. The surface of porous layers of indium phosphide under normal conditions of storage is covered by the oxide layer. Chemical analysis of the surface of porous InP (spectra were taken at 4 points - Fig. 12) revealed violations of stoichiometry of the original crystal. Oxygen atoms and a small fraction of fluorine atoms emerged at the surface of the sample (Table 2). It indicates creation of proper oxides of InP.

Overgrowing of porous nanomaterial with an oxide layer occurs for definite reasons. Porous surface is characterized by high density of surface states in the forbidden zone, which leads to fixing of the Fermi level, the position of which at the surface practically does not depend on the nature of adsorbed atoms [27]. This circumstance negatively affects the work of many micro- and optoelectronic devices, preventing complete revealing high potential abilities of these semiconductors. To eliminate undesirable surface influence on the properties of devices, the technique called "passivation" is actively developing in technology, within which a variety of methods of surface treatment, related to applying coverings on it, are designed [28].

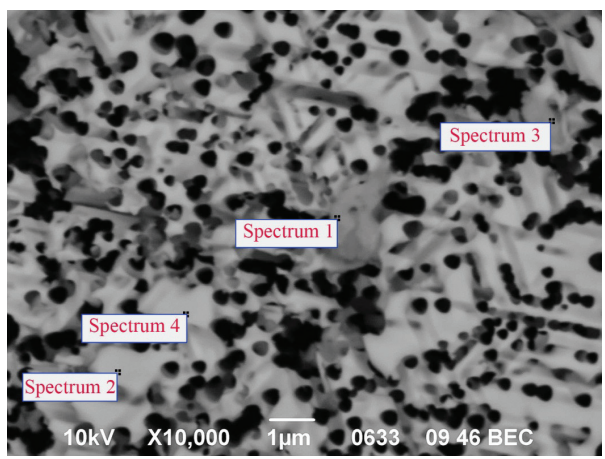

Fig. 12. Surface of por-InP:

$5 \%$ of $\mathrm{HCl}, \mathrm{j}=100 \mathrm{~mA} / \mathrm{cm}^{2}, \mathrm{t}=5 \mathrm{~min}$

Table 2

Percentage content of elements at the surface of porous $n$-InP, obtained with the help of EDAX method

\begin{tabular}{|c|c|c|c|}
\hline \multirow{2}{*}{ Spectrum } & \multicolumn{3}{|c|}{ Component } \\
\cline { 2 - 4 } & $\mathrm{O}$ & $\mathrm{P}$ & In \\
\hline Spectrum 1 & 17.46 & 22.12 & 60.42 \\
\hline Spectrum 2 & 2.76 & 22.36 & 74.88 \\
\hline Spectrum 3 & 3.80 & 22.10 & 74.10 \\
\hline Spectrum 4 & 3.80 & 22.10 & 74.10 \\
\hline
\end{tabular}

At chemical passivation, an oxide layer is removed from the surface of semiconductor, instead of which a thin crystalline film of chemically inert material is formed. This film can perform the functions of a superfine buffer layer and protect surface of the semiconductor from contact with aggressive components of the environment.

The layers of porous indium phosphide were kept in the $\mathrm{Na}_{2} \mathrm{~S}$ solution for $10 \mathrm{~min}$. During chalcogenide por-InP passivation the oxide layer is removed, a thin crystalline film of chemically and electrically inert material is formed instead of it. These nanomaterials may be stored under normal conditions in a special container, avoiding contact with aggressive substances. Porous indium phosphide does not dissolve in water; the solvent may be acids and alkali.

Stage 4 "Production of nanomaterial products InN/ por-InP”

Thin films of indium nitride on the substrate of porous indium phosphide were obtained by the method of ray-radical epitaxy (Fig. 13). The main difference of this method from the traditional epitaxy is that one component comes with gas phase (atomic nitrogen), and the other (indium) is obtained from the volume of the crystal [29]. As atomic nitrogen, especially pure ammonia is used, which passes through the high-frequency discharge, resulting in atomic nitrogen, which is a chemically active. A stream of atomic nitrogen gets on the crystal of indium phosphide (temperature of the sample is $400{ }^{\circ} \mathrm{C}$, time of experiment is 1.5 hours). It results in the process of conversion of surface layers. At the 
surface of porous InP, thin InN films emerge (Fig. 14). Table 3 shows basic properties of the resulting structure. A film of indium nitride is formed with the violation of stoichiometry toward indium (Table 4).

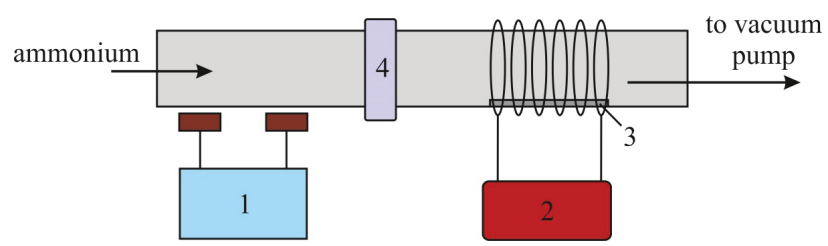

Fig. 13. Schematic of obtaining $\ln \mathrm{N}$ films on porous substrates of indium phosphide by the method of radicalbeam epitaxy: 1 - UVF generator; 2 - voltage source for heating samples; 3 - porous samples; 4 - control valve

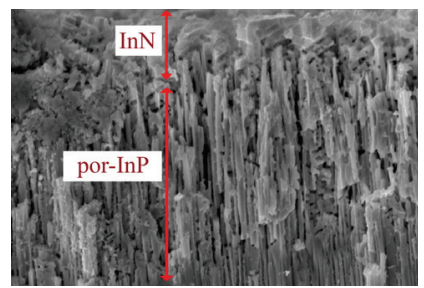

Fig. 14. InN film is formed at the surface of por-InP by the method of radical-beam epitaxy

Table 3

Properties of indium nitride

\begin{tabular}{|c|c|}
\hline Type of crystal lattice & wurtzite \\
\hline Lattice constant & $\begin{array}{c}\mathrm{a}=3.533 \div 3.548 \mathrm{~A}, \\
\mathrm{c}=5.693 \div 5.703 \div 5.760 \mathrm{~A}\end{array}$ \\
\hline Molar mass & $128,83 \mathrm{~g} / \mathrm{mol}$ \\
\hline Density in solid state & $6,86-6,91 \mathrm{~g} / \mathrm{cmi}$ \\
\hline Melting temperature & $1200^{\circ} \mathrm{C}$ \\
\hline Dielectric permittivity & $\begin{array}{c}\text { static }-12.5 ; \\
\text { high frequency }-9.61\end{array}$ \\
\hline Width of forbidden zone & $0,7-0,9 \mathrm{eV}$ \\
\hline Alloying impurities & $\begin{array}{c}\text { for n-type }-\mathrm{S}, \mathrm{Se}, \mathrm{Te}, \mathrm{Si}, \mathrm{Ge}, \mathrm{Sn} ; \\
\text { for p-type }-\mathrm{Zn}, \mathrm{Cd}\end{array}$ \\
\hline Solubility in water & does not solve \\
\hline Solvents & acid mixes at boiling \\
\hline
\end{tabular}

Table 4

Percentage content of elements at the surface of porous $\ln \mathrm{N} /$ por-InP, obtained by using the EDAX method

\begin{tabular}{|c|c|c|c|}
\hline \multirow{2}{*}{ Spectrum } & \multicolumn{3}{|c|}{ Component } \\
\cline { 2 - 4 } & $\mathrm{N}$ & $\mathrm{P}$ & In \\
\hline Spectrum 1 & 23.92 & 1.73 & 43.72 \\
\hline Spectrum 2 & 25.03 & 0.62 & 74.35 \\
\hline Spectrum 3 & 20.91 & 1.03 & 78.06 \\
\hline Spectrum 4 & 26.01 & 0.51 & 73.48 \\
\hline
\end{tabular}

Indium nitride may cause irritation of skin and eyes, pain in joints and bones, tooth decay, nervous and gastrointestinal disorders, pain in the heart and the overall weakness [30]. Acute and chronic toxicity of this substance are not known enough. Given high thermodynamic, electrical and chemical stability of indium nitride [31], it can be argued that its crystals may be considered conditionally safe under normal conditions.

Stage 4A "Testing and sorting of InN/por-InP structures"

The main problem of obtaining InN films on allogenic substrates is mismatching of periods of nitride film lattices and the used substrate [32]. This leads to a considerable number of defects emerging on the boundary of the InN film and the substrate and, as a consequence, poor quality of the produced InN films. A porous layer of indium phosphide serves as a buffer that is able to take elastic deformations, which arise in the process of its formation and further cooling, and provide drainage for dislocations of mismatching [33, 34].

Stage 5 "Usage of nanomaterials"

The structures, based on nitrides of the third group, have a predicted operation life of about 5 years [35, 36]. In this context, we imply retaining all electro-physical indicators at the output level. This is followed by a slow degradation of the structure surface. InN/InP is used as a raw material for solar cells whose operation life is 20 years.

Stage 6 "Reclamation and wastes"

As was noted above, the original nanomaterial is used as a raw material for products and devices, the reclamation of which is recommended to conduct with the "hazardous wastes" label [37]. Currently, there is a limited number of studies, devoted to the recycling of nanomaterials, and, until sufficient data are collected, such materials should be treated as hazardous.

\section{Discussion of results of the study of conducting nanomaterial control}

The main purpose of certification of nanomaterials is a confirmation of the possibility of recreating conditions of synthesis within permissible deviations, establishing suitability of using this nanomaterial in accordance with its purpose, detection of potential dangers of its usage.

The analysis, presented above, of quality control of porous indium phosphide at all stages of the life cycle allows making up a control card of por-InP (Table 5) according to the procedure, presented in Fig. 3. To identify the possible danger of nanoproduct, it is necessary to evaluate its indicators from its design stage to the reclamation stage. This approach might be applied in the analysis of other nanomaterials, taking into account their specific features.

Methods of measurement of parameters and properties of nanostructures is a fixed set of operations and regulations, compliance with which provides obtaining measurement results with guaranteed accuracy according to the adopted method. One may say that the method of measurement is the technology of measurement process. However, most methods are still at the stage of development and do not allow providing full control of quality and safety of nanomaterials. The main reasons for this are:

- lack of clear-cut requirements and standards for quality of nanomaterials;

- lack of standard samples of most nanomaterials;

- insufficient number of certified methods of measurement, calibration and validation, etc.

This direction needs further development and the government-level support. 
Table 5

Control card of quality and ecological safety of porous indium phosphide

\begin{tabular}{|c|c|c|}
\hline No. & Required information & Commentary \\
\hline 1 & Product name & Porous indium phosphide (por-InP). Form of production: plates \\
\hline 2 & Usage scope & $\begin{array}{c}\text { Technological purpose: raw material for manufacturing photoelectric power converters, } \\
\text { nitrides of the third group, LEDs, information transferring and storage devices }\end{array}$ \\
\hline 3 & Information about manufacturer (supplier) & - \\
\hline 4 & $\begin{array}{l}\text { Information about nanoparticles } \\
\text { content in material composition }\end{array}$ & $10-100$ pores per $\mathrm{mkm}^{2}$ (depending on conditions of formation) \\
\hline 5 & $\begin{array}{l}\text { Information about chemical composition } \\
\text { of nanoparticles, chemical composition of } \\
\text { components } \\
\end{array}$ & $\begin{array}{l}\text { Por-InP is composed of atoms of phosphorus and indium in ratio P:In=1:3. } \\
\text { In the process of storage may be covered by oxide film }\left(\operatorname{In}_{2} \mathrm{O}_{3}\right)\end{array}$ \\
\hline 6 & $\begin{array}{l}\text { Information about average dimensions of } \\
\text { particles and distribution of particles by } \\
\text { dimensions }\end{array}$ & Pores of average dimensions of $40 \mathrm{~nm}$, quantum wires $-5-10 \mathrm{~nm}$ \\
\hline 7 & $\begin{array}{c}\text { Information about existence of } \\
\text { cancerogenic substances in composition }\end{array}$ & indium is toxic metal, some phosphorus compounds are very toxic \\
\hline 8 & Information about impurities & Impurity $\mathrm{S}$ in the composition in concentration of $2,3 \times 1018 \mathrm{~cm}^{-3}$ \\
\hline 9 & Solubility & Is not soluble in water. Solvents are solutions of acids \\
\hline 10 & Methods of research & $\begin{array}{c}\text { Scanning electronic microscopy, atomic-power electronic spectroscopy, } \\
\text { photoluminiscence, X-ray diffraction analysis etc. }\end{array}$ \\
\hline 11 & $\begin{array}{l}\text { Information about the method of } \\
\text { obtaining nanomaterials }\end{array}$ & Electrochemical etching in solutions of acids \\
\hline 12 & Hazard class of nanoindustry product & Not regulated; recommended to carry a «Health hazard» sign \\
\hline 13 & Information about possible technogenic risks & Information is not available \\
\hline 14 & $\begin{array}{c}\text { Information about (if available) } \\
\text { toxicological and hygienic characteristics of } \\
\text { nanoindustry product }\end{array}$ & Indium phosphide is considered cancerogenic substance \\
\hline 15 & $\begin{array}{l}\text { Information (if available) about the impact of } \\
\text { nanoindustry product on environment }\end{array}$ & Information is not available \\
\hline 16 & $\begin{array}{l}\text { Rules of handling and storage of } \\
\text { nanoindustry product }\end{array}$ & $\begin{array}{c}\text { It is necessary to be accompanied by pictogram «Health hazard». } \\
\text { During synthesis and further use, it is necessary to use the means of } \\
\text { individual and collective protection }\end{array}$ \\
\hline 17 & Reclamation & «Hazardous wastes» \\
\hline 18 & Standardizing and legislative provision & Information is not available \\
\hline
\end{tabular}

\section{Conclusions}

1. A scheme of the life cycle of nanomaterials was developed, which should be considered as a multi-stage process from the preparation of source material to the reclamation. In this case, it is necessary to take into account additional stages - testing and sorting of samples.

2. It was established that the main purpose of assessing nanotechnological products is a safe and productive use of nanotechnology for the provision of ecological safety. The search for and development of methods of studying nanomaterials is required. Ecological estimation of nanotechnology products needs government regulation.

3. The methods for controlling quality and safety of nanomaterials and products based on them were presented.
It is necessary to exercise control at every stage of the lifecycle using appropriate techniques and methods of research. According to the proposed methods, an analysis of the samples of porous indium phosphide and a device based on it - indium nitride, was performed. It was found that porous indium phosphide is dangerous for health material.

\section{Acknowledgement}

Present study was conducted within the framework of the scientific state-funded research "Nanostructured semiconductors for power efficient ecologically friendly technologies that increase power efficiency and ecological safety of the urbosystem" (State registration number 0116U006961).

\section{References}

1. Kovtun, G. P. Nanomaterials: technology and Materials: A Review [Text] / G. P. Kovtun, A. A. Veryovkin. - Kharkiv: KIPT, 2010. $-73 \mathrm{p}$

2. Nanotechnology patents in USPTO (Patent) [Electronic resource]. - StatNano. - Available at: http://statnano.com/report/s103

3. Khrypunov, G. Increasing the efficiency of film solar cells based on cadmium telluride [Text] / G. Khrypunov, S. Vambol, N. Deyneko, Y. Sychikova // Eastern-European Journal of Eenterprise Technologies. - 2016. - Vol. 6, Issue 5 (84). - P. 12-18. doi: 10.15587/1729-4061.2016.85617

4. Suchikova, Y. Provision of environmental safety through the use of porous semiconductors for solar energy sector [Text]/ Y. Suchikova // Eastern-European Journal of Eenterprise Technologies. - 2016. - Vol. 6, Issue 5 (84). - P. 26-33. doi: 10.15587/17294061.2016.85848

5. Bremus-Koebberlinga, E. A. Nano structures via laser interference patterning for guided cell growth of neuronal cells [Text] E. A. Bremus-Koebberling, S. Beckemper, B. Koch, A. Gillner // Journal of Laser Applications. - 2012. - Vol. 24, Issue 4. P. 042013. doi: 10.2351/1.4730804 
6. Beckemper, S. Generation of Periodic Micro- and Nano-structures by Parameter-Controlled Three-beam Laser Interference Technique [Text] / S. Beckemper // Journal of Laser Micro/Nanoengineering. - 2011. - Vol. 6, Issue 1. - P. 49-53. doi: 10.2961/ jlmn.2011.01.0011

7. Suchikova, Y. A. Influence of dislocations on the process of pore formation in n-InP (111) single crystals [Text] / Y. A. Suchikova, V. V. Kidalov, G. A. Sukach // Semiconductors. - 2011. - Vol. 45, Issue 1. - P. 121-124. doi: 10.1134/s1063782611010192

8. Trifonova, T. A. Environmental safety of nanoparticles, nanomaterials and nanotechnologies [Text]: proc. manual / T. A. Trifonova, L. A. Shirkin. - Vladimir: Publishing House of Vlad. state. University, 2009. - 64 p.

9. American Society for Testing and Materials - ASTM [Electronic resource]. - Available at: http://www.astm.org/

10. Antsiferova, I. V. Production methods of nanomaterials and the potential environmental risks [Text] / I. V. Antsiferova, E. N. Makarova // Herald PNIPU. Machinery, Materials. - 2013. - Vol. 15, Issue 4. - P. 59-67.

11. Rajendran, V. Development of Nanomaterials from Natural Resources for Various Industrial Applications [Text] / V. Rajendran // Advanced Materials Research. - 2009. - Vol. 67. - P. 71-76. doi: 10.4028/www.scientific.net/amr.67.71

12. Jones, R. Are natural resources a curse? [Text] / R. Jones // Nature Nanotechnology. - 2007. - Vol. 2, Issue 11. - P. 665-666. doi: 10.1038/nnano.2007.351

13. Efros, A. L. Origin and control of blinking in quantum dots [Text] / A. L. Efros, D. J. Nesbitt // Nature Nanotechnology. - 2016. Vol. 11, Issue 8. - P. 661-671. doi: 10.1038/nnano.2016.140

14. Weidman, M. Monodisperse, Air-Stable PbS NanocrystalsviaPrecursor Stoichiometry Control [Text] / M. C. Weidman, M. E. Beck, R. S. Hoffman, F. Prins, W. A. Tisdale // ACS Nano. - 2014. - Vol. 8, Issue 6. - P. 6363-6371. doi: 10.1021/nn5018654

15. Wu, S. A Quick-responsive DNA Nanotechnology Device for Bio-molecular Homeostasis Regulation [Text] / S. Wu, P. Wang, C. Xiao, Z. Li, B. Yang, J. Fu et. al. // Scientific Reports. - 2016. - Vol. 6. - P. 31379. doi: 10.1038/srep31379

16. Zhou, C. Reversible Regulation of Protein Binding Affinity by a DNA Machine [Text] / C. Zhou, Z. Yang, D. Liu // Journal of the American Chemical Society. - 2012. - Vol. 134, Issue 3. - P. 1416-1418. doi: 10.1021/ja209590u

17. Sengul, H. Toward sustainable nanoproducts: An overview of nanomanufacturing methods [Text] / H. Sengul, T. L. Theis, S. Ghosh // Journal of Industrial Ecology. - 2008. - Vol. 12, Issue 3. - P. 329-359. doi: 10.1111/j.1530-9290.2008.00046.x

18. Meyer, D. E. An Examination of Existing Data for the Industrial Manufacture and Use of Nanocomponents and Their Role in the Life Cycle Impact of Nanoproducts [Text] / D. E. Meyer, M. A. Curran, M. A. Gonzalez // Environmental Science \& Technology. 2009. - Vol. 43, Issue 5. - P. 1256-1263. doi: 10.1021/es8023258

19. Dhingra, R. Sustainable Nanotechnology: Through Green Methods and Life-Cycle Thinking [Text] / R. Dhingra, S. Naidu, G. Upreti, R. Sawhney // Sustainability. - 2010. - Vol. 2, Issue 10. - P. 3323-3338. doi: 10.3390/su2103323

20. Theis, T. L. A life cycle framework for the investigation of environmentally benign nanoparticles and products [Text] / T. L. Theis, B. R. Bakshi, D. Durham, V. M. Fthenakis, T. G. Gutowski, J. A. Isaacs et. al. // physica status solidi (RRL) - Rapid Research Letters. - 2011. - Vol. 5, Issue 9. - P. 312-317. doi: 10.1002/pssr.201105083

21. Seager, T. P. Coupling Multicriteria Decision Analysis and Life Cycle Assessment for Nanomaterials [Text] / T. P. Seager, I. Linkov // Journal of Industrial Ecology. - 2008. - Vol. 12, Issue 3. - P. 282-285. doi: 10.1111/j.1530-9290.2008.00048.x

22. Sparvolia, M. Study of indium nitride and indium oxynitride band gaps [Text] / M. Sparvoli, R. D. Mansano, J. F. D. Chubaci // Materials Research. - 2013. - Vol. 16, Issue 4. - P. 850-852. doi: 10.1590/s1516-14392013005000063

23. Indium phosphide [Electronic resource]. - U. S. National Library of Medicine. - Available at: https://pubchem.ncbi.nlm.nih.gov/ compound/indium_phosphide\#section=2D-Structure

24. Suchikova, Y. A. Preparation of nanoporous n-InP (100) layers by electrochemical etching in HCI solution [Text] / Y. A. Suchikova, V. V. Kidalov, G. A. Sukach // Functional Materials. - 2010. - Vol. 17, Issue 1. - P. 131-134.

25. Sychikova, Y. A. Dependence of the threshold voltage in indium-phosphide pore formation on the electrolyte composition [Text] $/$ Y. A. Sychikova, V. V. Kidalov, G. A. Sukach // Journal of Surface Investigation. X-ray, Synchrotron and Neutron Techniques. 2013. - Vol. 7, Issue 4. - P. 626-630. doi: 10.1134/s1027451013030130

26. Suchikova, Y. A. Influence of the carrier concentration of indium phosphide on the porous layer formation [Text] / Y. A. Suchikova, V. V. Kidalov, G. A. Sukach // Journal of Nano- and Electronic Physics. - 2010. - Vol. 2, Issue 4. - P. $142-147$.

27. Liu, Y. Chemical passivation processes for biofunctionalization schemes on semiconductor surfaces [Text] / Y. Liu, J. Chen, A. V. Teplyakov // Langmuir. - 2012. - Vol. 28, Issue 44. - P. 15521-15528. doi: 10.1021/la302819j

28. Bessolov, V. N. Chalcogenide passivation of III-V semiconductor surfaces [Text] / V. N. Bessolov, M. V. Lebedev // Semiconductors. - 1998. - Vol. 32, Issue 11. - P. 1141-1156. doi: 10.1134/1.1187580

29. Suchikova, Y. A. Synthesis of indium nitride epitaxial layers on a substrate of porous indium phosphide [Text] / Y. A. Suchikova // Journal of Nano- and Electronic Physics. - 2015. - Vol. 7, Issue 3. - P. 03017-1-03017-3.

30. Indium Nitride(InN) Semiconductors [Electronic resource]. - AZoM. - Availableat: http://www.azom.com/article.aspx?ArticleID=8367

31. Sato, T. Electrochemical formation of N-type GaN and N-type InP porous structures for chemical sensor applications [Text] $/$ T. Sato, X. Zhang, K. Ito, S. Matsumoto, Y. Kumazaki // 2016 IEEE SENSORS. - 2016. doi: 10.1109/icsens.2016.7808443

32. Suchikova, Y. A. Usage of porous indium phosphide as substrate for indium nitride films [Text] / Y. A. Suchikova, V. V. Kidalov, A. A. Konovalenko, G. A. Sukach // ECS Transactions. - 2011. - Vol. 33, Issue 38. - P. 73-77. doi: 10.1149/1.3583516

33. Suchikova, Y. A. Blue shift of photoluminescence spectrum of porous InP [Text] / Y. A. Suchikova, V. V. Kidalov, A. A. Konovalenko, G. A. Sukach // ECS Transactions. - 2010. - Vol. 25, Issue 24. - P. 59-64. doi: 10.1149/1.3316113

34. Suchikova, Y. A. Effect of the type of electrolyte anion on the porous InP morphology obtained by the electrochemical etching [Text] / Y. A. Suchikova, V. V. Kidalov, G. A. Sukach // Journal of Nano- and Electronic Physics. - 2009. - Vol. 1, Issue 4. P. 111-118. 
35. Singh, P. Degradation Physics of High Power LEDs in Outdoor Environment and the Role of Phosphor in the degradation process [Text] / P. Singh, C. M. Tan // Scientific Reports. - 2016. - Vol. 6. - P. 24052. doi: 10.1038/srep24052

36. Tan, C. M. Time Evolution Degradation Physics in High Power White LEDs Under High Temperature-Humidity Conditions [Text] / C. M. Tan, P. Singh // IEEE Transactions on Device and Materials Reliability. - 2014. - Vol. 14, Issue 2. - P. 742-750. doi: 10.1109/tdmr.2014.2318725

37. Amoabediny, G. H. Guidelines for safe handling, use and disposal of nanoparticles [Text] / G. H. Amoabediny, A. Naderi, J. Malakootikhah, M. K. Koohi, S. A. Mortazavi, M. Naderi, H. Rashedi // Journal of Physics: Conference Series. - 2009. Vol. 170. - P. 012037. doi: 10.1088/1742-6596/170/1/012037

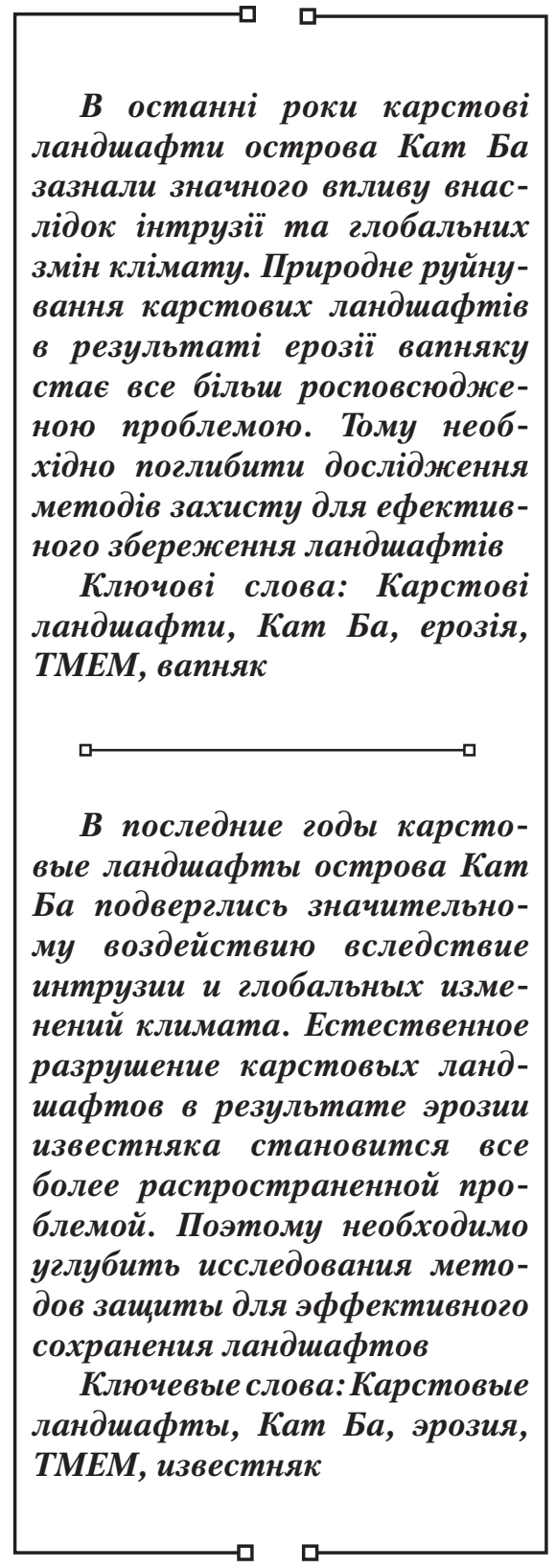

\section{Introduction}

The Cat Ba islands consisting of 367 islands are the third largest island group, behind The Phu Quoc and Cai Bau islands. However, The Cat Ba Islands are the biggest limestone islands in tropical Southeast Asia, also are the largest islands in Halong Bay Area with high potential for scientific

\section{EROSION STUDY OF LIMESTONE ON THE Cat Ba ISLANDS IN NORTH EAST VIETNAM BY TRANSVERSE MICRO-EROSION METER}

Nguyen Trung Minh $\mathrm{PhD}$, Associate Professor, Director*

Email: nttminh@vast.vn

Doan Dinh Hung

Master of Science, Researcher* Email: doandinhhung@gmail.com

Nguyen Thi Dung Master of Science, Researcher* Email: nguyendungVAST@gmail.com

Tran Minh Duc

Bachelor of Science, Researcher* Email: minhduc.hus@gmail.com

$\mathbf{N g u y e n ~ B a ~ H u n g}$ Bachelor of Science, Researcher* Email: hungdc53@gmail.com

C u S y Thang

Master of Science, Researcher

Institute of Geological Sciences

Vietnam Academy of Science and Technology Alley 84 Chua Lang Street, Dong Da District, Hanoi, Vietnam

Email: cusythang@yahoo.com

*Vietnam National Museum of Nature Vietnam Academy of Science and Technology Building A20, No.18 Hoang Quoc Viet Street, Cau Giay Street, Hanoi, Vietnam 